\title{
Online teaching learning during COVID-19 pandemic : perception and challenges faced by teachers
}

\author{
Ramesh Subba', Hem Kumari Subba ${ }^{2}$
}

\section{Author(s) info:}

${ }^{1}$ Department of Psychiatric Nursing, School of Nursing, Chitwan Medical College, Bharatpur-10, Nepal

${ }^{2}$ Department of Adult Health Nursing, School of Nursing, Chitwan Medical College, Bharatpur-10, Nepal

\section{Correspondence:}

\section{Hem Kumari Subba}

Department of Adult Health

Nursing, School of Nursing,

Chitwan Medical College,

Bharatpur-10, Nepal

\section{Email:}

hrsubba@gmail.com

DOI :

https://doi.org/10.3126/jpsn.v2i1.42589

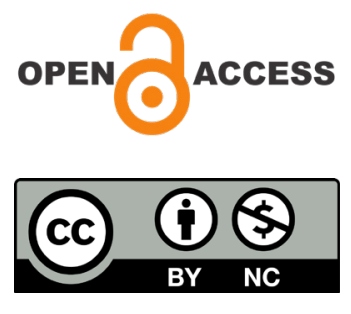

๑ JPSN

\begin{abstract}
Introduction: Online teaching can play a vital role in the process of teaching and learning during COVID-19 pandemic. However, teachers' perceptions and challenges are major factors in the adoption and effectiveness of online teaching learning, especially at institutions where it is newly adopted. This study aimed to investigate the perception and challenges faced by nursing teachers regarding online teaching learning during the pandemic in Bharatpur, Chitwan.
\end{abstract}

Materials and methods: A web-based cross-sectional survey was undertaken among 162 nursing teachers of different nursing colleges of Chitwan actively involved in online teaching learning for undergraduate and postgraduate programs during the pandemic. Non-probability enumerative sampling technique was used to select the sample. A structured questionnaire consisting of 23 items (5-point Likert scale) covering four domains for teachers perception (usefulness, ease of use, system use and behavioral intention toward online teaching learning) was distributed to the teachers using Google Form from 2021 June 5th to 2021 July 20th. Collected data were analyzed using descriptive and inferential statistics.

Results: More than half (56.2\%) of the teachers had good perception towards online teaching learning during COVID 19 pandemic. Teachers faced challenges to implement online teaching learning such as poor internet connection, electricity problem, difficult to assemble all the students for the class, difficult for interaction with students, and lack of information technology skills.

Conclusions: Despite having to confront numerous challenges in the online teaching process, teachers can demonstrate the positive perception toward technology of online teaching. Teachers need to be equipped with e-learning technology for effectiveness of online teaching classes.

Keywords: COVID-19 pandemic, online teaching learning, teachers' perception 


\section{INTRODUCTION}

Corona virus disease 2019 (COVID-19) is an infectious disease, first identified in Wuhan, China, in December 2019 became declared pandemic status on March 12, 2020.[1] This pandemic affects everyone and everywhere in the world and confronted with unprecedented challenges. Different countries have implemented varying quarantine measures, restriction in free movement, interruption many daily activities, trade, and, in especially, education.[2] The COVID-19 pandemic has developed many disruption on education systems around the world, affecting around 1.6 billion students across 190 countries and continents. School and other learning space closures have affected 94 percent of the world's student population, with up to 99 percent in low and lower-middle income nations.[3]

Since the outbreak of Corona virus in Nepal, the government has decided to put the country on lockdown starting March 24, 2020 to combat its spread.[4] Since then, the lockdown has been extended several times and it has had a negative impact on several sectors, including education. All levels of education were started using online learning from home as instruction of Ministry of Education. Online education is now the best possible alternative to face to face learning.[5] As a result, numerous medical institutions have been attempting to implement new technology to facilitate online learning as a primary mode of teaching through the usage of different online learning platform applications like Zoom, Google Classroom, Google Meet, Microsoft etc.[6, 7]

Online teaching learning is not that simple for a country like Nepal; it is a enormous challenges for both teachers and students. Online classes has several benefits[8,9] and limitations.[10] Several studies found that there are many factors considered as obstacles to online learning such as lack of appropriate materials and resources, technical problems, lack of in service training, difficulty in assembling all the students for the class, lack of cooperation from the parents, lack of internet facilities to the students, difficulty to follow up the learning of students[11]; the expensive internet cost, and the family financial crisis.[12]

Regarding teachers perception, teachers showed a positive perception of the usefulness and ease of online learning systems during pandemic in
Indonesia, still, more than half of teachers didn't agree on its effectiveness.[13] In a recent study in India found many positive and negative attitudes regarding online education.[14] Similarly, it was found that teachers had a positive perception of using technologies in Italy[15] and recommend that teachers' digital skills must be developed as part of their professional development in order to prepare for future educational activities.[15,16]

There are many studies that show the conditions of students experiencing online education but comparatively fewer studies are conducted describing the circumstances of the teachers in this regard. Therefore, teachers' perceptions and challenges of online teaching are crucial to facilitate an effective online learning environment; the benefits and barriers to implementation must be understood. So, this study aims to investigate the perception and challenges faced by nursing teachers regarding online teaching learning during COVID 19 pandemic in Nepal.

\section{MATERIALS AND METHODS}

A descriptive cross sectional survey was used among 162 nursing teachers of different nursing colleges of Chitwan who were actively involved in online teaching learning. There are total 14 nursing colleges in Chitwan where total 217 nursing teachers were engaged in teaching learning activities for Proficiency Certificate Level, undergraduate and post graduate nursing students. A non-probability enumerative sampling technique was used to select the sample. Ethical approval was obtained from Chitwan Medical College Institutional Review Committee (Ref. no: CMC-IRC/ 077/078-262).

A structured self-administered questionnaire was developed based on prior literature that relate to online teaching learning and content validity was maintained by consulting with experts in the field of medical education. The research instrument was consisted demographic characteristics, information about online classes, perceptions and challenges of online classes. The perceptions of online teaching questionnaire consisted of 23 questions which contained 4 domains; usefulness, ease of use, system use and behavioral intention toward online teaching learning. The questions were designed by using a Likert Scale of five items: Strongly Agree (SA):, Agree (A), Neutral (N), Disagree (A), and Strongly Disagree (DA). Total score was 115, higher score indicated good perception. 
The questionnaire was then imported into Google Forms and was piloted among 50 teachers from different colleges who were not included in the final study. To verify the reliability of the instrument, Cronbach's alpha was calculated using the pilot study data. The resultant Cronbach's alpha for the instrument was 0.88 indicating that the tool was reliable for further study.

Questionnaire link using 'Google Form' was sent to all the eligible 167 teachers through email, Facebook $^{\oplus}$, or Messenger ${ }^{\circledR}$. Prior to starting the survey, the purpose, voluntary nature of participation and confidentiality and anonymity of given responses were clarified with respondents. After reading, respondents gave their consent to participate by clicking either "Yes" or "No." The form was made accessible to the teachers from 2021 June 5th to 2021 July 20th. The survey response data was collected online and was only available to the researchers in a non-identifiable form. The respondent's response rate was $97 \%$. The data was exported to Microsoft Excel 2016 and was analyzed by using IBM SPSS version 20 for window. Standard descriptive statistics was used to describe the data, utilizing median, frequency, percentage as appropriate and inferential analysis (Chi-square) test was used to measure the association between levels of perception towards online teaching learning during COVID 19 pandemic and selected variables. $\mathrm{P}$ value $<0.05$ was considered to be statistically significant.

\section{RESULTS}

Out of 162 , the median age of teachers was 33 years, range 24 years to 56 years. More than half of teachers had completed master's degree and the others had completed bachelor's degree. Regarding designation, most were lecturers and the median working experience of respondents was 5 years (range: 3 months to 27 years). [Table 1]

Regarding respondents' online teaching related information, more than four-fifths $(82.7 \%)$ of the teachers spent more than 2 hours time in online teaching. Almost all teachers (91.4\%) were taking online classes from their own home. Less than half (45.1\%) teachers had past experience on online teaching and only a small portion (14.2\%) had taken training on online teaching. All teachers used WiFi for online class, almost all used laptop or both

Table: 1 Socio demographic characteristics of the respondents $(n=162)$

\begin{tabular}{|l|c|c|}
\hline \multicolumn{1}{|c|}{ Variables } & Frequency & Percentage \\
\hline \begin{tabular}{|l|l|}
\hline Age (in completed years) \\
$\quad<33$
\end{tabular} & 78 & \\
\hline$\geq 33$ & 84 & 51.9 \\
\hline $\begin{array}{l}\text { Median age=33 years, } I Q R=Q 3-Q 1=37-29, \text { min }=24 \\
\text { Qualification }\end{array}$ & \\
\hline Bachelor & & \\
\hline Master & 76 & 46.9 \\
\hline Designation & 86 & 53.1 \\
\hline Assistant lecturer & & \\
\hline Lecturer & 63 & 38.9 \\
\hline Senior Lecturer & 70 & 43.2 \\
\hline Instructor & 4 & 2.5 \\
\hline Assistant Professor & 6 & 3.7 \\
\hline Associate Professor & 13 & 8.0 \\
\hline Working Experience (in Years) & 6 & 3.7 \\
\hline Less than 5 & 73 & 45.1 \\
\hline Equal and more than 5 & 89 & 54.9 \\
\hline Median =5 years, IQR=Q3-Q1=8-2, mini=3 months, max=27 years & \\
\hline
\end{tabular}


Table: 2 Respondents' online teaching related information $(\mathrm{n}=162)$

\begin{tabular}{|c|c|c|}
\hline Variables & Frequency & Percentage \\
\hline \multicolumn{3}{|c|}{ Spent time on online classes per day } \\
\hline$<2$ hours & 28 & 17.3 \\
\hline$\geq 2$ hours & 134 & 82.7 \\
\hline \multicolumn{3}{|l|}{ Median $=2$ hrs., range 1 to 7 hours } \\
\hline \multicolumn{3}{|l|}{ Taking online class } \\
\hline Home & 148 & 91.4 \\
\hline Office & 14 & 8.6 \\
\hline \multicolumn{3}{|c|}{ Previous online teaching experience } \\
\hline Yes & 73 & 45.1 \\
\hline No & 89 & 54.9 \\
\hline \multicolumn{3}{|c|}{ Training on online teaching learning } \\
\hline Yes & 23 & 14.2 \\
\hline No & 139 & 85.8 \\
\hline \multicolumn{3}{|l|}{ Types of device for on line teaching } \\
\hline Smart phone & 3 & 1.9 \\
\hline Laptop & 93 & 57.4 \\
\hline Both Laptop and Smart phone & 66 & 40.7 \\
\hline \multicolumn{3}{|c|}{ Preference of Learning Environment } \\
\hline Class room learning & 144 & 88.9 \\
\hline e-learning & 18 & 11.1 \\
\hline
\end{tabular}

Table: 3 Respondents' challenges faced during online teaching $(n=162)$

\begin{tabular}{|c|l|c|c|c|}
\hline $\begin{array}{c}\text { S. } \\
\text { N. }\end{array}$ & \multicolumn{1}{|c|}{ Challenges } & Not at all & $\begin{array}{c}\text { To some } \\
\text { extent }\end{array}$ & $\begin{array}{c}\text { To great } \\
\text { extent }\end{array}$ \\
\hline & & No. $(\%)$ & No. (\%) & No. (\%) \\
\hline 1 & Lack of appropriate materials and resources & $27(16.7)$ & $116(71.6)$ & $19(11.7)$ \\
\hline 2 & Technical problems (Poor net connection) & $12(7.4)$ & $92(56.8)$ & $58(35.8)$ \\
\hline 3 & Lack of time & $91(56.2)$ & $63(38.9)$ & $8(4.9)$ \\
\hline 4 & Problem in electricity & $27(16.7)$ & $101(62.3)$ & $34(21.0)$ \\
\hline 5 & It is difficult to assemble all the students for the class & $13(8.0)$ & $96(59.3)$ & $53(32.7)$ \\
\hline 6 & Difficult for interaction with students & $12(7.4)$ & $87(53.7)$ & $63(38.9)$ \\
\hline 7 & Lack of internet facilities to the students & $10(6.2)$ & $108(66.7)$ & $44(27.2)$ \\
\hline 8 & It is difficult to follow up the learning of students & $7(4.3)$ & $99(61.1)$ & $56(34.6)$ \\
\hline 9 & Unable to read the face and mood of students & $5(3.1)$ & $55(34.0)$ & $102(63.0)$ \\
\hline 10 & Students are not following the time table as in regular classes & $43(26.5)$ & $92(56.8)$ & $27(16.7)$ \\
\hline 11 & Lack of IT skills & $41(25.3)$ & $99(61.1)$ & $22(13.6)$ \\
\hline 12 & Suffering from eye pain & $42(25.9)$ & $77(47.5)$ & $43(26.5)$ \\
\hline 13 & Suffering from neck pain & $46(28.4)$ & $81(50.0)$ & $35(21.6)$ \\
\hline 14 & Suffering from headache & $43(26.5)$ & $84(51.9)$ & $35(21.6)$ \\
\hline
\end{tabular}


Table no 4: Association between respondent's level of perception towards online teaching and selected variables $(\mathrm{n}=162)$

\begin{tabular}{|c|c|c|c|c|}
\hline \multirow[b]{2}{*}{ Variables } & \multicolumn{2}{|c|}{ Level of Attitude } & \multirow[b]{2}{*}{$\chi^{2}$ value } & \multirow[b]{2}{*}{ p value } \\
\hline & $\begin{array}{l}\text { Positive } \\
\text { No. (\%) }\end{array}$ & $\begin{array}{l}\text { Negative } \\
\text { No. (\%) }\end{array}$ & & \\
\hline \multicolumn{3}{|l|}{ Age in years } & \multirow[t]{3}{*}{0.707} & \multirow[t]{3}{*}{0.141} \\
\hline$<33$ & $45(57.7)$ & $33(42.3)$ & & \\
\hline$\geq 33$ & $46(54.8)$ & $38(45.2)$ & & \\
\hline \multicolumn{3}{|l|}{ Professional qualification } & \multirow[t]{3}{*}{0.294} & \multirow[t]{3}{*}{1.102} \\
\hline Bachelor & $46(60.5)$ & $30(39.5)$ & & \\
\hline Master & $45(52.3)$ & $41(47.7)$ & & \\
\hline \multicolumn{3}{|l|}{ Working experience } & \multirow[t]{3}{*}{0.204} & \multirow[t]{3}{*}{1.616} \\
\hline$<5$ years & $45(61.6)$ & $28(38.4)$ & & \\
\hline$\geq 5$ years & $46(51.7)$ & $43(48.3)$ & & \\
\hline \multicolumn{3}{|l|}{ Previous Experience on online teaching } & \multirow[t]{3}{*}{0.752} & \multirow[t]{3}{*}{0.100} \\
\hline Yes & $42(57.5)$ & $31(42.5)$ & & \\
\hline No & $49(55.1)$ & $40(44.9)$ & & \\
\hline \multicolumn{3}{|l|}{ Training } & \multirow[t]{3}{*}{0.676} & \multirow[t]{3}{*}{0.174} \\
\hline Yes & $12(52.2)$ & $11(47.8)$ & & \\
\hline No & $79(56.8)$ & $60(43.2)$ & & \\
\hline
\end{tabular}

laptop and smart phone for taking online classes. Only a small portion (11\%) preferred e-learning to classroom teaching.. [Table 2]

Regarding challenges faced by teachers on online teaching during COVID 19 pandemic, majority (71.6\%) of the teachers complained of lack of appropriate materials and resources to some extent and to great extent by a small portion. Technical problems (poor internet connection) faced as a challenge to some extent by $56.8 \%$ teachers while $35.8 \%$ to great extent. Majority $(62.3 \%)$ faced problem in electricity to some extent. More than fifty percent (56.2\%) teachers had no problem for time management.

More than fifty percent $(59.3 \%)$ teachers found some difficult to assemble all the students for the class to some extent while $32.7 \%$ had difficulty to great extent. Similarly, $54.7 \%$ faced difficult for interaction with students while teaching in some extent and $61.1 \%$ of the teachers found it difficult to follow up the learning of students in some extent. It was found that $63.0 \%$ of the teachers faced problem with reading face and mood of students to great extent because students usually turned off their video.
Similarly, 56.8\% teachers observed that students were not following the time table as in regular classes to some extent. Majority (61.1\%) teachers faced challenges in information technology (IT) skills to some extent. Many physical problems were also complained by teachers such eye pain, neck pain and headache. [Table 3]

Out of 162 respondents, more than half (56.2\%) had positive perception towards online teaching whereas others $(43.8 \%)$ had negative perception towards online teaching learning during COVID 19 pandemic

In relating the level of perception towards online teaching learning during COVID 19 pandemic with respondents' socio- demographic and professional related variables, significant association was not observed for any of the variables. [table 4]

\section{DISCUSSION}

The COVID-19 pandemic has led to the development of new teaching approaches in medical education including a transition from traditional "face-to-face or physical teaching-learning process" 
to online instruction. We found that majority of teachers had positive perception towards online teaching whereas $43.8 \%$ had negative perception. This finding is supported by other studies, where teachers have a highly positive and favorable attitude towards online teaching.[11,17] Similarly, during the Covid-19 pandemic, teachers had a positive perception of the usefulness and ease of online teaching learning system. Still, more than half of teachers disagreed about its effectiveness. Despite the fact that teachers confront many challenges in the online teaching process, they can demonstrate the proper attitude toward using technology to teach online.[13]

Online teaching is a great choice for teaching during the lockdown period, and it will be more beneficial in completing the syllabus. It does, however, create a communication gap between teachers and students. Our study showed that the greater challenges faced by nursing teachers on online teaching learning process during COVID-19 pandemic are lack of appropriate materials and resources, technical problems (poor net connection), problem in electricity, difficult to assemble all the students for the class, difficult for interaction with students, lack of internet facilities to the students, difficult to follow up the learning of students, unable to read the face and mood of students, students are not following the time table as in regular classes and lack of IT skills to some extent to greater extent. More than fifty percent $(56.2 \%)$ teachers had no problem for time management for online teaching. This is supported by study conducted in India which showed that lack of appropriate materials and resources, technical problems, lack of in service training, difficulty in assembling all the students for the class, lack of cooperation from the parents, lack of internet facilities to the students, difficulty to follow up the learning of students are the major challenges faced by teachers.[11]

Although online classes have made a significant contribution to closing the education gap, oneway contact during online classes appears to be a problem that impedes effective learning. In this study, most of the teachers $(88.9 \%)$ were preferred for classroom teaching than e-learning. Most of the teachers $(85.8 \%)$ had not received training and $45.1 \%$ had past experience on online teaching. This lack of previous experience as well as lack of training on online teaching might be causing a difficult situation for the teachers.
Adapting online education for a developing country like Nepal in the pandemic time is a huge problem in itself. Online education has revolutionized the way we learn, but a year and a half of taking classes from home has resulted in several mental (stress and anxiety, lack of interest) and physical health problems for both students and teachers such as fatigue, eyesight problems, lack of physical activities, bad ergonomics etc.[18] Our study revealed that some physical problems faced by teachers such as eye pain, neck pain and headache to some extent $47.5 \%, 50.0 \%$ and $51.9 \%$ respectively. Similarly, A study done in Nepal showed that both students and teachers have faced similar health situations due to the online classes. The most common health problems were eye pain, back pain, and headache.[19]

The findings of this study suggest that while diverse stakeholders are more prepared to implement online teaching learning, there is still improvements to be made. This study's result is also expected to serve as a foundation and guide for future efforts to improve the quality of online teaching learning. Implementing online teaching learning successfully necessitates good preparation. [20] Thus all teachers must be trained to make the system easy and concerned authority need to adopt new education policies and regulations to promote online teaching learning system among teachers in order to facilitate gradual transition from traditional teaching to online teaching learning.

Apart from that, this study also has certain limitations. First, this research focuses on the teacher's perception and challenges towards online teaching learning based on one point of view, namely the teacher. In subsequent analysis, the opinions of students and parents also need to be comprehensively expressed. Second, the participants of this study were from nursing colleges from only one District, posing a threat to the study's external validity. If a more diverse group of people had been contacted, the outcomes of this study would have been better.

\section{CONCLUSION}

The perceptions and challenges of teachers are major factors in the adoption of online teaching learning and its effectiveness. Our study found that more than half of the teachers have positive perception with online teaching learning. However, teachers faced various challenges to implement online 
teaching learning such as poor internet connection, problem in electricity, difficult for interaction with students, lack of IT skills etc. These problems need to be considered in unison while implementing online teaching learning program in order to boost the positive perception rate among teachers.

\section{CONFLICT OF INTEREST}

None.

\section{REFERENCES}

1. World Health Organization Coronavirus disease 2019 (COVID-19). March 26, situation report - 66. 2020. https://www.who.int/docs/default-source/coronaviruse/ situation-reports/20200326-sitrep-66-covid-19.pdf

2. Alzahrani SB, Alrusayes AA, Aldossary MS. Impact of COVID-19 pandemic on dental education, research, and students. Int J of Health Sci and Res 2020 Jun;10:20712. https://www.ijhsr.org/IJHSR_Vol.10_Issue.6_ June2020/32.pdf

3. United Nation . Policy Brief: Education during COVID-19 and beyond. August 2020. https://www. un.org/development/desa/dspd/wp-content/uploads/ sites/22/2020/08/sg_policy_brief_covid-19_and_ education_august_2020.pdf

4. The Kathmandu Post. Government extends lockdown until May 18. 2020, May 6.

5. Fami T, Tariq SB. Is online education system suitable for Bangladesh? The Business Standard. 28 July 2020. https:// www.tbsnews.net/thoughts/online-education-systemsuitable-bangladesh-112546

6. Kaur N, Dwivedi D, Arora J, Gandhi A. Study of the effectiveness of e-learning to conventional teaching in medical undergraduates amid COVID-19 pandemic. National J of Physi, Pharmacy and Pharma 2020;10(7):1. DOI: 10.5455/njppp.2020.10.04096202028042020

7. Baczek $M$, Zagańczyk-Bączek $M$, Szpringer $M$, Jaroszyński A, Wożakowska-Kapłon B. Students' perception of online learning during the COVID-19 pandemic: A survey study of Polish medical students. Medicine (Baltimore). 2021;100(7):e24821. DOI: 10.1097/MD.0000000000024821

8. Al-Husban NA. Critical Thinking Skills in Asynchronous Discussion Forums: A Case Study. Int I of Technology in Educ 2020;3(2):82-91. DOI: https://doi.org/10.46328/ijte. v3i2.22

9. Seage SJ, Türegün M. The Effects of Blended Learning on STEM Achievement of Elementary School Students. Int $J$ of Res in Education and Sci 2020;6(1):133-40. DOI: https://doi.org/10.46328/ijres.v6i1.728

10. Weinhandl R, Lavicza Z, Hohenwarter M, Schallert S. Enhancing flipped mathematics education by utilizing GeoGebra. Int J of Educ in Math, Sci and Technology 2020 Jan 12;8(1):1-5. DOI: https://doi.org/10.46328/ijemst. v8i1.832

11. Sareen S, Nangia A. Online Teaching during COVID 19: Attitude and Challenges faced by School Teachers. Int J of Disaster Recovery and Business Continuity. 2020; 11(1), 3012-3018.

12. Ramij MG, Sultana A. Preparedness of Online Classes in Developing Countries amid COVID-19 Outbreak: A Perspective from Bangladesh (SSRN Scholarly Paper ID 3638718). Social Science Research Network.

13. Rahayu RP, Wirza Y. Teachers' perception of online learning during pandemic Covid-19. Jurnal Penelitian Pendidikan 2020;20(3):392-406. DOI: https://doi. org/10.17509/jpp.v20i3.29226

14. Arora $A K$, Srinivasan R. Impact of pandemic COVID-19 on the teaching-learning process: A study of higher education teachers. Prabandhan: Ind J of Management 2020 Apr 30;13(4):43-56. DOI: 10.17010/pijom/2020/ $v 13 i 4 / 151825$

15. Giovannella C, Marcello P, Donatella P. The effects of the Covid-19 pandemic on Italian learning ecosystems: The school teachers' Perspective at the steady state. Interaction Design and Architecture(s) J IxDßA, 2020;.45: 264 - 286

16. Klapproth F, Federkeil L, Heinschke F, Jungmann T. Teachers' Experiences of Stress and Their Coping Strategies during COVID-19 Induced Distance Teaching. J. of Pedagogical Res 2020;4(4):444-52. https://doi. org/10.33902/JPR.2020062805

17. Dubey DB, Singh DS. Perception of teachers on online teaching in higher education during covid-19 lockdown. Int I of Creative Research Thoughts 2020;8(5):1017-22.

18. India Today. New Delhi. September 18, 2021. Effects of online education on mental and physical health.

19. Megh Raj Dangal, Rubin Maharjan. Health Problems Experienced in Online Learning During COVID-19 in Nepali Universities. Int $J$ of Online Graduate Educ 2021;4(1)

20. Aliyyah RR, Rachmadtullah R, Samsudin A, Syaodih E, Nurtanto $M$, Tambunan AR. The perceptions of primary school teachers of online learning during the COVID-19 pandemic period: A case study in Indonesia. J of Ethnic and Cultural Stud 2020;7 (2): 90-109. 